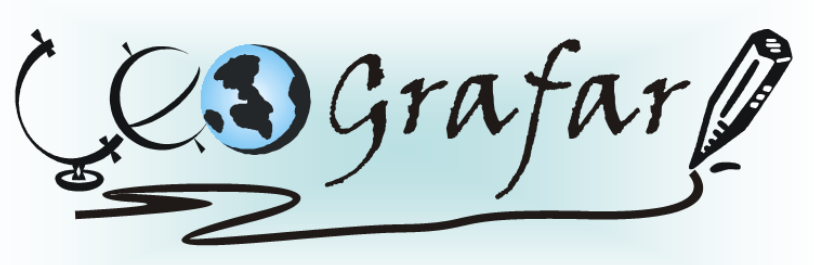

Revista Eletrônica do Programa de Pós-Graduação em Geografia - UFPR

\title{
QUALIDADE AMBIENTAL NAS PAISAGENS URBANIZADAS
}

\author{
ALEXANDRE THEOBALDO BUCCHERI FILHO ${ }^{1}$ \\ EMERSON LUIS TONETTI ${ }^{2}$
}

\begin{abstract}
RESUMO
A urbanização provoca alterações nos processos naturais, porém, se o crescimento, tanto em área quanto em volume for rápido demais e sem considerar o planejamento da paisagem, as consequências negativas para a qualidade ambiental são: a poluição, os congestionamentos, os ruídos, a falta de espaços livres públicos e de áreas verdes. Por isso a verificação da qualidade ambiental nas cidades é cada vez mais importante. Considerando o ambiente urbano como o conjunto de fatores do meio físico, pode-se avaliar a qualidade deste ambiente por meio das consequências, para o ambiente e para os seres humanos, inferidas com base no uso e na ocupação do solo. Podem ser inferidas as conseqüências para a qualidade do ar, da água e do solo, com base na poluição que possivelmente os usos potencialmente poluidores, tais como postos de gasolina, serralherias, mecânicas, vias com tráfego intenso etc., estejam gerando. As áreas com riscos de inundações também podem ser mapeadas e inseridas como situação que diminui a qualidade ambiental. Áreas sem vegetação, sem espaços livres públicos, com alta densidade demográfica e muito verticalizadas podem ser, também, consideradas como áreas com menor qualidade ambiental. Tendo estas considerações, o presente artigo tem como objetivo listar e discutir alguns critérios para serem utilizados em trabalhos de avaliação da qualidade ambiental urbana.
\end{abstract}

Palavras chave: qualidade ambiental urbana, planejamento da paisagem.

\footnotetext{
1 Doutor em Geografia (DGEOG - UFPR), professor da rede pública de ensino do Estado do Paraná. abuccheri@gmail.com

Graduação e mestrado em Biologia (UFPR), doutorando em Geografia (DGEOG - UFPR), professor do IFPRParanaguá. emersontonetti@gmail.com
} 


\title{
ENVIRONMENTAL QUALITY IN THE URBANIZED LANDSCAPES
}

\begin{abstract}
Urbanization causes changes in the natural processes, however, if the growth of both area and volume is too fast and does not consider the landscape planning, the negative consequences for environmental quality are: pollution, traffic jams, noise, the lack of public open spaces and green areas. Therefore the verification of environmental quality in cities is becoming increasingly important. Considering the urban environment as a set of physical factors which are part of the city, one can evaluate the quality of this environment analyzing the consequences for the physical environment and for the humans, inferred based on the use and the occupation of the land. The consequences for air quality, water and soil, can be inferred based on the pollution that possibly the potentially polluting uses such as gas stations, sawmills, garages, roads with heavy traffic etc., are generating. The areas at risk of flooding can also be mapped and considered as a situation that reduces the environmental quality. Areas with no vegetation, no public open spaces, overpopulated and with a large amount of buildings may also be considered as areas with lower environmental quality. Taking all this into consideration, this article aims to list and discuss some criteria to be used in studies of the urban environmental quality.
\end{abstract}

Keywords: urban environmental quality, landscape planning.

\section{INTRODUÇÃO}

Nas cidades um ambiente saudável e o crescimento concorrem diretamente entre si, pois, em sua maioria, não são projetadas levando em consideração a preocupação com a qualidade do ambiente. Para Buccheri-Filho (2006), os cidadãos usufruem as inovações tecnológicas e seus confortos, porém, sofrem com a deterioração do ambiente devido à poluição, congestionamentos, ruídos e com a falta de vegetação e de espaços livres públicos para o lazer.

A importância da verificação da qualidade ambiental nas cidades é cada vez mais evidente, pois chegamos ao século XXI com a maior parte da população do planeta vivendo nas cidades e segundo Lombardo (1985), “(...) é no espaço urbano que os problemas ambientais atingem maior amplitude, notando-se maior concentração de poluentes do ar e da água e degradação do solo e subsolo, em consequência do uso intenso do território pelas atividades urbanas". Com estes pontos citados, mostra-se a preocupação com o crescimento desordenado das 
cidades sobre o ambiente natural, "(...), pois agrega cimento no lugar da vegetação e pessoas em substituição aos animais” (GARCIA, 1997), agravando o problema da qualidade ambiental que prioriza, dentre outras coisas "o contato do homem urbano com a natureza, tornando a vida nos grandes centros menos desagradável" (FREIRIA, 2001).

Tanto na Constituição Federal (BRASIL, 1988) quanto na Política Nacional de Meio Ambiente (BRASIL, 1981), na Política Nacional de Resíduos Sólidos (BRASIL, 2010) e no Estatuto da Cidade (BRASIL, 2001) consta que todos têm direito ao ambiente com qualidade, para ter a boa qualidade de vida. Essas considerações também constam no nível municipal, estando geralmente presentes no plano diretor e na lei orgânica dos municípios. No entanto, em nenhuma destas instâncias apresenta-se uma definição de qualidade ambiental e poucos são os parâmetros citados e os meios para atingi-la. Apesar disso, essas normativas e as informações científicas indicam que locais onde a qualidade do ambiente urbano não é adequada não devem sofrer processo de adensamento e se ocorrer, as condições inadequadas devem ser eliminadas para que 0 ambiente esteja dentro de parâmetros adequados para os habitantes viverem.

Apesar do conceito de qualidade ambiental urbana ser muito citado na literatura científica e na legislação, continua pouco considerado na prática. BuccheriFilho (2006) comenta que os fatores culturais e sociais são fundamentais para o bem-estar da sociedade humana, contudo os fatores do meio físico também possuem extrema importância, mas infelizmente, são esquecidos ou negligenciados no planejamento dos centros urbanos.

Esses fatores são os aspectos físicos, químicos e biológicos das áreas urbanizadas que influenciam a qualidade do ambiente. Se a qualidade é baixa, tais fatores podem limitar o adensamento populacional e o crescimento das edificações porque não atendem as necessidades humanas mínimas (NUCCI, 2008; TRICART, 1977). No entanto, o conceito de qualidade ambiental pode ser facilmente confundido com o de qualidade de vida e influenciar na escolha dos critérios e, consequentemente, gerar resultados confusos.

Nesse sentido, a revisão de conceitos realizada por Kamp et al. (2003) facilita a distinção entre os conceitos de qualidade ambiental e qualidade de vida, ao 
colocar o primeiro conceito como um componente do segundo, que além da questão ambiental, envolve os aspectos sociais, econômicos e de saúde, entre outros.

Define-se, portanto, para este trabalho, que ambiente urbano se refere ao conjunto de fatores do meio físico urbano, que o conceito de qualidade ambiental urbana é parte de um conceito mais abrangente que é o conceito de qualidade de vida e que qualidade ambiental urbana é a amplitude de condições favoráveis do ambiente urbano, que suprem as necessidades fisiológicas e psicológicas do ser humano.

Desta forma, os estudos da qualidade ambiental urbana tentam manter essas condições dentro de parâmetros aceitáveis para as necessidades humanas nas áreas urbanizadas. Assim, busca-se o que o ambiente oferece e não o que o ser humano quer ou faz no ambiente.

O estudo de muitos dos fatores que constituem o ambiente urbano pode ser feito por meio de coleta de dados e medições com utilização de instrumentos e posterior realização de análises laboratoriais e computacionais para verificar se os valores identificados encontram-se dentro dos limites previamente determinados, por exemplo, pela legislação. Outro tipo de análise pode ser feito por meio de inferências, ou seja, principalmente por meio de um mapeamento detalhado dos usos do solo, pode-se inferir, de forma qualitativa, a potencialidade da qualidade ambiental urbana, sendo essa última o modelo adotado neste trabalho.

Uma forma qualitativa de avaliação da qualidade ambiental urbana é encontrada no método desenvolvido por Nucci (1996, 1998, 2001 e 2008). Resumidamente, o método consiste na espacialização e sobreposição das condições desfavoráveis ou dos parâmetros negativos dos critérios ambientais, que caracterizam menor qualidade ambiental. Da ausência das condições desfavoráveis até a sobreposição do maior número de parâmetros negativos, tem-se uma perda potencial da qualidade ambiental.

Esse método segue a linha da ecologia e do planejamento da paisagem, que evolui como ramo de estudo da ciência da paisagem, na geografia. A ecologia e planejamento da paisagem, de forma sintética, é uma teoria do planejamento que incorpora os princípios ecológicos na avaliação das potencialidades (limites e aptidões) da natureza e da paisagem para acolher os usos humanos (NUCCI, 1996, 
2001, 2008, 2009 e 2010).

De acordo com as considerações expostas acima, este artigo, tem como objetivo listar e discutir critérios para serem utilizados em trabalhos de avaliação da qualidade ambiental urbana, dentro da linha da ecologia e planejamento da paisagem.

\section{MÉTODO}

Devido ao caráter teórico do presente artigo, os procedimentos para sua elaboração consistiram primeiramente na análise de trabalhos referentes ao tema, para elencar os conceitos mais relevantes para serem utilizados como critérios em possíveis avaliações da qualidade ambiental, de acordo com a proposta de Nucci (2008). Posteriormente, para cada conceito, quando possível, com base na bibliografia consultada, foram selecionados os parâmetros para balizar o aspecto positivo ou negativo do critério em trabalhos empíricos. Estes parâmetros são apresentados ao logo da discussão de cada conceito.

Neste momento, cabe destacar que dentro deste tema existem inúmeros critérios que poderiam ser utilizados na avaliação da qualidade ambiental urbana. Esta breve revisão não pretende esgotar o assunto nem ser a única nem a última versão a respeito da evolução dos conceitos e dos parâmetros a eles relacionados. Considerando o contexto e especificidade de cada cidade, outros critérios do ambiente podem ser mais relevantes do que os listados a seguir.

\section{RESULTADOS E DISCUSSÕES}

\subsection{CLIMA E POLUIÇÃO ATMOSFÉRICA}

O crescimento da população e da industrialização, associado à mudança de costumes (valores), tem aumentado expressivamente as mudanças climáticas, principalmente em uma escala local, como por exemplo, nas áreas urbanas.

As diferentes atividades humanas dentro dos espaços internos de uma área urbanizada (parques, indústrias, prédios, etc.) somados a configuração e distribuição 
destes espaços, podem contribuir, consideravelmente, para variações climáticas, configurando diversos tipos de microclimas.

A questão sobre as variações climáticas dentro de uma pequena área urbana, devido às diferenças das atividades ou construções é levantada por Spirn (1995), afirmando que "(...) cada cidade é composta por um mosaico de microclimas radicalmente diferentes, os quais são criados pelos mesmos processos que operam na escala geral da cidade (...)", acrescentando ainda que “(...) os mesmos fenômenos que caracterizam o mesoclima urbano existem em miniatura por toda a cidade - pequenas ilhas de calor, microinversões, bolsões de grave poluição atmosférica e diferenças locais no comportamento dos ventos (...)". Esta idéia é contemplada por Lombardo (1985) a qual afirma que "as condições climáticas de uma área urbana extensa e de construção densa são totalmente distintas daquelas dos espaços abertos circundantes, podendo haver diferenças de temperatura, de velocidade do vento, de umidade, de pureza do ar, etc.".

Ayoade (1983) corrobora essas informações ao afirmar que o maior impacto sobre o clima acontece nas áreas urbanas, onde os componentes naturais são substituídos por superfícies pavimentadas, ruas e telhados, que alteram a composição química da atmosfera, as propriedades térmicas e hidrológicos da superfície terrestre.

Lombardo (1985) afirma que "(...) a urbanização, considerada em termos de espaço físico construído, altera significativamente o clima urbano, considerando-se o aumento das superfícies de absorção térmica, impermeabilização dos solos, alterações na cobertura vegetal, concentração de edifícios que interferem nos efeitos dos ventos, contaminação da atmosfera através da emanação dos gases".

Segundo Mota (1999), os principais fatores climáticos relacionados com a urbanização são: radiação solar, temperatura, velocidade e direção dos ventos, precipitação, umidade e camadas atmosféricas. A incidência dos raios solares dentro das áreas urbanas depende da distribuição e dos tipos de construção encontrados dentro das cidades. A temperatura está diretamente relacionada com a urbanização, como áreas e/ou ruas pavimentadas, as quais absorvem calor durante o dia e dissipam à noite, aumentando expressivamente a temperatura. Algumas diferenças qualitativas com o entorno rural são listadas no quadro 1. 


\begin{tabular}{|c|c|c|c|}
\hline \multirow{2}{*}{\multicolumn{2}{|c|}{ ELEMENTOS }} & \multicolumn{2}{|c|}{ ALTERAÇÃO } \\
\hline & & MAIOR & MENOR \\
\hline RADIAÇÃO & $\begin{array}{l}\text { global } \\
\text { ultravioleta no inverno } \\
\text { ultravioleta no verão } \\
\text { duração da exposição a luz }\end{array}$ & & $\begin{array}{c}2 \text { a } 20 \% \\
30 \% \\
5 \% \\
5 \text { a } 15 \%\end{array}$ \\
\hline TEMPERATURA & $\begin{array}{l}\text { média anual } \\
\text { média das mínimas no inverno }\end{array}$ & $\begin{array}{c}0,5 \text { a } 2^{\circ} \mathrm{C} \\
1 \text { a } 2^{\circ} \mathrm{C}\end{array}$ & \\
\hline VELOCIDADE DO VENTO & $\begin{array}{l}\text { média anual } \\
\text { dias sem vento }\end{array}$ & 5 a $20 \%$ & 10 a $30 \%$ \\
\hline PRECIPITAÇÃO & $\begin{array}{l}\text { total } \\
\text { dias com menos de } 5 \mathrm{~mm}\end{array}$ & $\begin{array}{c}5 \text { a } 30 \% \\
10 \%\end{array}$ & \\
\hline NEBULOSIDADE & $\begin{array}{l}\text { cobertura } \\
\text { nevoeiro no inverno } \\
\text { nevoeiro no verão }\end{array}$ & $\begin{array}{c}5 \text { a } 10 \% \\
100 \% \\
30 \%\end{array}$ & \\
\hline UMIDADE RELATIVA DO AR & $\begin{array}{l}\text { no inverno } \\
\text { no verão }\end{array}$ & & $\begin{array}{c}2 \% \\
8 \mathrm{a} 10 \%\end{array}$ \\
\hline CONTAMINANTES & $\begin{array}{l}\text { núcleos de condensação } \\
\text { misturas gasosas }\end{array}$ & $\begin{array}{r}10 \text { vezes } \\
5 \text { a } 25 \text { vezes }\end{array}$ & \\
\hline
\end{tabular}

QUADRO 1 - CONDIÇÕES CLIMÁTICAS PROVOCADAS PELA URBANIZAÇÃO QUANDO COMPARADAS COM O ENTORNO RURAL

FONTE: adaptado de MOTA (1999, p. 35) e SUKOPP e WERNER (1991, p. 23)

Existe também o problema da pavimentação e consequente escoamento mais rápido da água, o que, por conseguinte, cria uma diminuição da água no solo que estaria disponível para ser evaporada e, assim, favorecer um maior resfriamento da superfície terrestre.

Outra questão relacionada ao clima em áreas urbanizadas e verificada por vários autores, tais como Ayoade (1983), Lombardo (1985), Danni-Oliveira (2003), entre outros, é a formação de ilhas de Calor ou Ilhas Térmicas. Este fenômeno está diretamente relacionado a condicionantes decorrentes das ações do homem no meio urbano, em termos de uso do solo e os condicionantes do meio físico e seus atributos geoecológicos. Com a urbanização, tem-se um expressivo aumento da impermeabilização do solo pelas construções e pavimentações. A verticalização, devido ao aumento da superfície de concreto, aumenta a capacidade térmica do local.

"Uma das conseqüências da ilha de calor na cidade é a formação de uma circulação do ar característica, onde o ar da região central se aquece e sobe, e o ar da periferia converge para o centro da cidade, onde se encontra o pico da ilha de calor, formando-se, assim, um domo de poluição sobre a cidade" (NUCCI, 2008). Isso pode ocorrer devido ao ar que vem da periferia, originalmente limpo e úmido, 
penetra na cidade adquirindo poluentes e diminuindo a sua umidade relativa, devido a ausência de áreas verdes e a concentração de tráfego. Este ar vai migrando para o centro da cidade, carregando altos índices de poluentes, podendo se agravar se houver "aprisionamento de poluentes" na cidade devido a uma inversão térmica decorrente da absorção de luz solar pelas partículas, as quais podem reagir, intensificando essa inversão, criando um domo de poluição. Provavelmente se os prédios e construções em geral tivessem mais espaços livres com o predomínio de áreas verdes ao seu redor, melhoraria, dentre outras coisas, a qualidade climática do local, pois, "estaria favorecendo a incidência de radiação solar, as trocas dos fluxos de calor e de umidade, bem como a dispersão de poluentes, na medida em que estaria criando uma permeabilidade entre os prédios" (DANNI-OLIVEIRA, 2003). Com isso, vê se que cada edifício é responsável por alterações microclimáticas, que se somando, criam um clima característico, diferentemente de uma área não verticalizada (NUCCI, 2008).

Outro aspecto que deve ser levado em consideração para avaliar o clima e a poluição nas áreas urbanizadas são os automóveis e outros veículos que, em quantidades excessivas dentro das cidades, aumentam as temperaturas e contribuem para a emissão de poluentes no ar. Segundo Branco (1995), indiferentemente do combustível que utilizem, os veículos geram poluentes sempre pelas mesmas fontes: escapamento, sistema de alimentação de combustível, cárter, desgaste de pneus e freios, sendo que, congestionamentos e/ou veículos parados em marcha lenta, emitem altas concentrações de monóxido de carbono, hidrocarbonetos e aldeídos. Isso tende a aumentar devido ao crescimento acelerado das cidades que, por conseguinte, aumenta o tráfego de veículos. Nucci (2008) afirma que "com o aumento de carros em circulação, além de piorar o trânsito, a quantidade de poluentes na atmosfera também aumenta, além do aumento do estresse, aumento de atropelamentos, etc.".

Drew (1989) coloca que "o escapamento dos veículos motorizados forma um grupo de poluentes atmosféricos que inclui o monóxido de carbono e o bióxido de nitrogênio". Em certas áreas, onde a insolação tem forte incidência, essas substâncias podem ter sua composição química alterada, formando novos compostos, muitas vezes nocivos para o homem. Margulis (1996), comenta que a maioria dos poluentes do ar origina-se "da combustão incompleta de combustíveis 
fósseis, para fins de transporte (...) e entre estas fontes de transporte contam-se automóveis, ônibus, caminhões (...)". A autora ainda afirma que "quando a concentração de poluentes do ar aumenta, sem que este seja adequadamente disperso pela ação da meteorologia, da topografia e de outros fatores, sérios problemas de saúde acabam ocorrendo".

Esta preocupação com a emissão de gases e partículas provenientes das indústrias e dos veículos motorizados é um dos tópicos da Política Nacional do Meio ambiente (BRASIL, 1981).

Quanto à poluição atmosférica Spirn (1995) comenta que "respirar o monóxido de carbono, encontrado freqüentemente nos maiores cruzamentos, dentro dos automóveis no tráfego pesado (...) pode causar dores de cabeça, cansaço e tontura. A autora ainda afirma que certos acidentes de trânsito são decorrentes da perda de coordenação motora causada pela inalação de monóxido de carbono.

Jackson (2003) afirma que nos centros urbanos os problemas respiratórios, como asma, estão relacionados com o aumento dos níveis de poluentes emitidos pelos automóveis, principalmente em locais onde há muitos carros e o movimento é lento. Esta autora cita pesquisas realizadas em centros urbanos onde uma redução no número de automóveis resultou em uma redução no número de internações hospitalares por problemas respiratórios, sem que houvesse redução do número de internações ocasionadas por outras doenças.

Segundo Branco (1995), todos os poluentes atmosféricos que exercem direta ou indiretamente efeitos nocivos ao homem, geralmente, são nocivos aos animais e plantas. Estas, apesar de certa suscetibilidade, podem atuar como filtro, reduzindo o nível de poluentes ( $\mathrm{NUCCl}, 2008)$ ou como isolante térmico, proporcionando inclusive redução nos gastos com energia (HOUGH, 1998). Este autor ainda comenta que as copas das árvores de uma rua podem absorver grandes quantidades de energia e reduzir a temperatura em até $6^{\circ} \mathrm{C}$ em relação a ruas não sombreadas.

Um ponto importante para a verificação da poluição atmosférica seria o emprego de algumas plantas como indicadores. Existem espécies de liquens que não se desenvolvem em locais onde a poluição está presente, com isso, poderia se verificar a presença ou não, da poluição atmosférica na localidade onde estas fossem inseridas. Ainda quanto as plantas como indicadores de poluição, 
"aboboreiras e plantas de cevada são também bons indicadores, sendo colocadas pelos pesquisadores em diferentes locais da cidade para constatação de efeitos inibidores sobre o seu desenvolvimento" (BRANCO, 1995).

Nesse contexto, a partir do estudo do uso do solo, pode-se inferir uma classificação positiva ou negativa para a qualidade ambiental, para o critério clima urbano e poluição atmosférica por meio das potenciais consequências que a distribuição e altura inadequadas dos edifícios podem gerar para o meio físico e para os seres humanos. O mesmo pode ser feito para a qualidade do ar, da água e do solo, com base na poluição que possivelmente os usos potencialmente poluidores, tais como postos de gasolina, serralherias, mecânicas, vias com tráfego intenso etc., estejam gerando (NUCCl, 1996, 1998, 2001 e 2008).

\subsection{COBERTURA VEGETAL}

A cobertura vegetal que reveste as áreas urbanizadas tem um papel importante na constituição da qualidade ambiental. Segundo Luchiari (2001) “(...) dentre os elementos que diferenciam as áreas residenciais uma das outras é a porção destinada à cobertura vegetal. Essa vegetação pode estar em áreas públicas ou privadas e constitui um dos indicadores da qualidade ambiental".

Quanto à importância da vegetação, Monteiro (1976) comenta que “(...) a necessidade que o homem tem de vegetação extrapola um valor meramente sentimental ou estético". Sitte (1992) ressalta que "(...) nem sequer um arbusto poderia ser sacrificado em nome de inevitáveis construções na cidade - ao contrário, toda a vegetação existente deveria ser ampliada através de novas arborizações".

Mascaró (1996), Nucci e Cavalheiro (1999), Puppi (sem data) citam várias funções relacionadas à vegetação nas cidades, tais como: controle da radiação solar, da temperatura, da umidade do ar, da ação dos ventos, da chuva, da poluição sonora, do ar, da água e do solo, entre outros benefícios.

Os pontos acima citados deixam clara a importância da vegetação nas cidades, melhorando além da qualidade ambiental, as condições para a vida dos cidadãos. 
O conceito de cobertura vegetal pode ser definido, segundo Cavalheiro et al. (1999), como “(...) a projeção do verde em cartas planimétricas e pode ser identificada por meio de fotografias aéreas, sem auxílio de estereoscopia", acrescentando ainda que "a escala da foto deve acompanhar os índices de cobertura vegetal; deve ser considerada a localização e a configuração das manchas (em mapas)", considerando ainda "a cobertura vegetal existentes nos sistemas de espaços construídos, espaços livres e as encontradas nas Unidades de Conservação (que na maioria restringem o acesso ao público), inclusive na zona rural".

A quantificação da cobertura vegetal nas cidades é um ponto importante, porém, de difícil solução, pois "problemas de definição de termos associados com a quantificação dessa vegetação, dificulta a proposição de critérios mais exatos que ajudariam na elaboração de leis de defesa da qualidade de vida da população urbana" (NUCCl e CAVALHEIRO, 1999).

Oke (1973 apud LOMBARDO, 1985) “(...) estima que um índice de cobertura vegetal na faixa de $30 \%$ seja recomendável para proporcionar um adequado balanço térmico em áreas urbanas, sendo que, áreas com índice de arborização inferior a 5\% são consideradas desertos florísticos". Sukopp e Werner (1991) sugerem que $33 \%$ da superfície de centros urbanos sejam ocupados por vegetação, por espaços livres de edificação ou por superfícies não pavimentadas.

Sobre a classificação da cobertura vegetal, Jim (1989) apresenta um estudo realizado em Hong Kong, no qual cria uma classificação para os diferentes tipos de mancha de cobertura vegetal arbórea conforme sua forma e distribuição espacial. Nucci e Cavalheiro (1999) traduziram estas categorias com o propósito de auxiliar na verificação de áreas com déficit de cobertura vegetal e no melhor planejamento da distribuição da vegetação nas áreas urbanizadas. No entanto, apesar da sua importância, o estudo de Jim (op. cit.) poderia considerar o porte da vegetação, pois "a quantidade e a distribuição de suas categorias, ou seja, herbácea, arbustiva ou arbórea, estão relacionadas com conforto térmico, com a qualidade do ar, escoamento superficial, uso pela população, etc." (MOURA e NUCCI, 2005).

Hough (1998) comenta que do ponto de vista climático em uma cidade, uma distribuição mais uniforme de pequenos espaços arborizados é mais efetiva que a concentração de poucos lugares grandes, estes necessitando ser complementados 
com um grande número de pequenos parques através da área construída para facilitar o deslocamento horizontal das massas de ar de diferentes temperaturas.

As possíveis perdas na qualidade ambiental das áreas urbanas decorrentes da ausência ou da reduzida ocorrência da cobertura vegetal podem ser avaliadas a partir da espacialização das manchas com vegetação visualizadas em fotos aéreas ou imagens de satélite em uma escala definida (NUCCI, 1996, 1998, 2001 e 2008).

\subsection{ESPAÇOS LIVRES E ÁREAS VERDES}

Cavalheiro et al. (1999) definem espaços livres como “(...) espaços urbanos ao ar livre, destinados a todo tipo de utilização que se relacione com caminhadas, descanso, passeios, práticas de esporte e, em geral, a recreação e entretenimento em horas de ócio. Os locais de passeios a pé devem oferecer segurança e comodidade (...)". Llardent (1982) comenta que os espaços livres devem ser destinados aos pedestres em oposição ao uso motorizado. Cavalheiro et al. (1999) acrescentam que "(...) os caminhos devem ser agradáveis, variados e pitorescos; os locais onde as pessoas se locomovem por meios motorizados não devem ser considerados como espaços livres". Os autores ainda indicam que os espaços livres podem ser públicos (praças, parques, etc.), potencialmente coletivos (por exemplo: escolas que abram suas portas para o lazer e recreação da comunidade nos fins de semana), ou privados (clubes esportivos, clubes de campo, etc.).

Um tipo especial de espaço livre seria a área verde onde o elemento fundamental de composição é a vegetação (CAVALHEIRO et al., 1999).

A preocupação com a vegetação nas cidades não é uma questão recente, Sitte (1992), no século XIX, já expressava o sentimento e a necessidade do contato do homem urbano com o verde, ressaltando que “(...) nós, a cada ano, precisamos refugiar-nos junto à natureza, ao menos durante algumas semanas, para continuarmos suportando a cidade por mais um ano inteiro". Isto mostra a importância do verde como uma necessidade dentro das cidades.

Howard (1996) ao citar a importância da função ecológica e de lazer do verde urbano na cidade de Paris, comenta que “(...) a reestruturação de Paris no século XIX visou proporcionar, dentre outras coisas, espaços abertos e verdes para melhorar a salubridade da cidade e o lazer de sua população". 
Para Cavalheiro et al. (1999) uma área verde deve cumprir três funções principais: ecológica, estética e recreativa, acrescentando que: “(..) considera-se função ecológica desempenhada pelas áreas verdes na cidade, a estabilização de determinadas superfícies, obstáculo contra o vento, proteção da qualidade da água, filtração do ar, equilíbrio do índice de umidade, redução dos ruídos, suporte para a fauna, etc. A função estética relaciona-se com a diversidade de emoções e sentimentos que a área verde suscita".

Puppi (Sem data) afirma que entre as funções dos espaços livres com predomínio de vegetação (áreas verdes), prevalecem os que concernem à higiene, ao saneamento e à estética, porém, aspectos sociais e econômicos devem ser igualmente levados em conta. Ainda sobre as funções das áreas verdes, Mascaró (1996) comenta que a arborização em praças não apenas reduz a ventilação local de maneira decisiva, mas também impede a acumulação de calor no solo e nas fachadas, estabelecendo um microclima homogêneo e definido, com menor temperatura e maior umidade. Isso leva a crer que praças com predomínio de vegetação em localidades muito quentes podem demonstrar uma expressiva redução de temperatura, mas ainda se comportar como um local quente, porém, agradável face à alta temperatura em seu entorno, o qual nem com ventilação mais intensa poderia amenizar (MASCARÓ, 1996).

Jackson (2003) salienta que a exposição dos habitantes à luz natural e ventilação, as oportunidades de observação, contato e a proximidade de espaços verdes colaboram na restauração da saúde física e mental. Afirma, também, que nos edifícios os moradores dos apartamentos situados nos andares mais elevados estão associados com baixa atividade física, problemas de comportamento, dificuldades respiratórias e isolamento social, o que pode agravar os problemas de coração, câncer e depressão. As pesquisas também demonstram que a falta de contato social é tão prejudicial quanto o tabagismo, obesidade, pressão sangüínea elevada e que os espaços verdes podem informalmente aumentar o contato social entre as pessoas.

Portanto, devido a grande importância dos espaços livres e áreas verdes para a qualidade ambiental e para a saúde dos seres humanos, além da preocupação com a conceituação e classificação dos espaços livres e áreas verdes, é também 
necessário planejar a distribuição espacial, o número e tamanho desses espaços na área urbanizada para que possam atender toda população.

Buccheri-Filho (2010) comenta que todos esses espaços são de uso público e por isso dá outra conotação ao termo. Esse autor (opus cit.) simplifica a confusão de termos, ao propor a utilização de "espaços de uso público, livres de edificação com e sem vegetação" e sugere a sigla EUPLEV para a primeira.

As propostas dos planejadores públicos geralmente não se preocupam com a distribuição dessas áreas na cidade, sua localização em relação a poluição, seu tamanho mínimo, a faixa etária de demanda entre outras características que devem ser consideradas (NUCCI, 2008). No entanto, muitos estudos recentes (BELEM e NUCCI, 2008; BUCCHERI-FILHO, 2006 e 2010; MOURA, 2010; NUCCI, 2008; SCHMIDT, 2009, entre outros) destacam a importância dos espaços livres.

Puppi (sem data), comenta que de modo geral bastaria a fração de 15\% à 20\% da superfície urbana para a utilização de espaços livres públicos, porém, o autor afirma que essa recomendação seria de caráter geral, pois, "deve-se ponderar que a área relativa demandada pelos espaços livres cresce com a densidade demográfica e com a população", sendo que, os grandes centros e as zonas mais adensadas são os que necessitam mais dos benefícios proporcionados pelos logradouros públicos recobertos pela vegetação (áreas verdes).

Jambor e Szilágyi (1984 apud NUCCI, 2008) sugerem regulamentações para os espaços livres dentro das cidades. "Em cidades com mais de 10.000 habitantes um total de 21 a 30 metros quadrados de espaços livres públicos por habitante deve ser assegurado, e dividido da seguinte forma:

- de 7 a 10 metros quadrados por habitante devem estar junto às habitações formando jardins residenciais isolados dos distúrbios do tráfego, industriais, etc.

- de 7 a 10 metros quadrados por habitante devem formar parques de vizinhança públicos, situados no máximo a 400 metros das residências. Devem facilitar, diariamente e nos fins de semana, as atividades esportivas e recreação ao ar livre.

- de 7 a 10 metros quadrados por habitante devem formar parques urbanos ou distritais de 20 a 80 ha, com um raio de ação de 2 a 3 km (...)"(op. cit.).

Nucci et al. (2005) comenta que nas propostas de adensamento elaboradas pelas Prefeituras, a disponibilidade de infra-estrutura e de espaço físico são as principais questões consideradas, não se importando com a quantidade, qualidade e 
distribuição de espaços livres que possam permitir o saudável contato do cidadão com a natureza, fornecendo também possibilidades de socialização e expressão cultural.

Apesar do estímulo ao crescimento das cidades em detrimento da qualidade ambiental, pode-se ainda constatar que há localidades urbanas que apresentam uma boa qualidade ambiental, principalmente por disponibilizarem espaços livres públicos, com vegetação e infra-estrutura de recreação, como os espaços designados como Jardim Ambiental I e II estudados por Buccheri-Filho (2006) no bairro Alto da XV (Curitiba), que exerciam as funções ecológica, estética e de lazer para a população residente ao redor.

Áreas sem espaços de uso público e livres de edificações com ou sem vegetação podem ser consideradas como áreas com menor qualidade ambiental. É possível delimitar esses espaços por meio da capacidade de habitantes que eles são capazes de atender (NUCCl, 1996, 1998, 2001 e 2008) ou utilizar a distância do espaço livre em relação à habitação (TONETTI, 2010).

\subsection{POLUIÇÃO SONORA}

A poluição acústica/sonora (excesso de ruído) pode ser considerada "como uma das principais formas de poluição ambiental, sendo responsável por impactos negativos com prejuízos ao meio ambiente e à qualidade de vida da população" (PAZ, 2004).

O aumento da poluição sonora está atrelado diretamente ao alto índice de crescimento demográfico, conseqüência do processo de urbanização, o qual gera mais fontes deste tipo de poluição, como o aumento das atividades de construção civil, aumento da demanda de veículos, ruas com tráfego mais intenso, congestionamentos, etc. afetando diretamente a qualidade ambiental.

A Prefeitura do Município de Curitiba (CURITIBA, 2005) considera poluição sonora, na Lei n.10.625/02, "emissão de som ou ruído que seja, direta ou indiretamente, ofensiva ou nociva a saúde, à segurança e ao bem estar da coletividade (...)".

Cada indivíduo apresenta reações diferentes ao ruído, dependendo, entre outros fatores, "de seu estado emocional e de sua personalidade" (CALIXTO, 2002). 
Sendo assim, ruído pode ser definido "como som indesejável (...)", e normalmente "é o resultado das atividades humanas do dia-a-dia" (DINIZ, 2003).

Calixto (2002) caracteriza o ruído "pela existência de muitas amplitudes e freqüências ocorrendo ao mesmo tempo de maneira não harmônica", acrescentando que o ruído "é associado a uma sensação não prazerosa".

Para Regazzi e Araújo (2002) o ruído "é o som capaz de causar uma sensação indesejável e desagradável". O autor ressalta que o que é desagradável para uma pessoa pode não ser para outra, dependendo de vários fatores, dentre eles o estado de espírito em que o indivíduo se encontra, da subjetividade de cada um, etc. Porém, os critérios para estabelecer a caracterização de ruído terão sua variável contida com base na compreensão do que se quer avaliar como poluição sonora, do que venha a ser fonte, a sua intensidade e a sua duração.

Segundo a Organização Mundial de Saúde (WHO, 2005) “(...) o agente caracterizador da poluição sonora urbana é denominado de ruído urbano ou ruído ambiental, considerado um ruído complexo, pois, é composto de várias parcelas diversas de ruídos secundários, provenientes de fontes de atividades diversas".

Zorzal et al. (2003) comenta que o ruído urbano "está estritamente ligado aos movimentos intensos de massas, ao congestionamento, acidentes e seus entraves, notadamente maiores nos horários de pico de trânsito; é o famoso horário de rush". Santos (2001) afirma que, avenidas de tráfego intenso (trânsito intenso) e corredores de tráfego podem se tornar problemas de saúde pública quando ofendem, além dos moradores localizados as margens destas, pessoas que passam próximos a elas.

Nucci (2008) afirma que as principais fontes de ruídos no meio urbano são: meios de transportes terrestres (carros, ônibus, caminhões, etc.), aeroportos, obras de construção civil em geral, aparelhos eletrodomésticos e o próprio comportamento do ser humano, sendo que, todas estas fontes em excesso, são prejudiciais ao organismo humano. Zorzal et al. (2004) ainda sobre as principais fontes de ruído coloca que "(...) a instalação de comércio e indústria em áreas antes estritamente residenciais agrava ainda mais o problema" acrescentando ainda que “(...) na poluição ambiental urbana, o ruído ambiental é uma conseqüência direta não desejada das próprias atividades que ocorrem nas grandes cidades".

Trabalhadores expostos freqüentemente a altos níveis de ruídos e moradores, nas mesmas condições, que vivem próximos das vias de tráfego intenso podem ser 
os indivíduos mais afetados pela poluição sonora. De acordo com Mota (1999) os principais efeitos do ruído urbano excessivo são a perda gradativa da audição, a irritabilidade, o incômodo, a exaustão física, os distúrbios psíquicos, as perturbações do sistema nervoso central, as perturbações cardíacas e circulatórias.

Murgel (1999) aponta que "a poluição sonora é em realidade uma questão importante de saúde pública e é considerada responsável, nos centros urbanos, por gerar ou agravar condições de estresse, podendo ser agente contribuinte em enfermidades graves decorrentes deste quadro, como os problemas cardíacos".

Apesar de cada indivíduo apresentar reações diferentes ao ruído, existem patamares para certos tipos de poluição sonora, e, de acordo com especialistas entrevistados pelo jornal Folha de São Paulo (02/05/2002 apud ZORZAL et al., 2003) os ruídos entre 50 a 60 decibéis podem causar leve incômodo em pessoas mais sensíveis; 61 a 70 decibéis podem causar desconforto, irritabilidade, mudança no humor e dificuldade de concentração; 71 a 80 decibéis aumento da pressão arterial e do batimento cardíaco, fadiga e disfunções gastrointestinais; 81 a 90 decibéis perda auditiva e dor de cabeça; e, acima de 100 decibéis pode causar dor e perda auditiva. Para a Organização Mundial de Saúde (1980) o nível de ruído de 55 decibéis pode causar distúrbios no sono; 70 decibéis seria o limite do considerado seguro, podendo comprometer a aprendizagem; 75 decibéis, irritação e desconforto; 80 decibéis, aumento dos batimentos cardíacos, descarga de adrenalina no organismo e hipertensão; 90 decibéis, danos ao sistema auditivo; 110 decibéis, danos permanentes à audição; e, 140 decibéis limite máximo da audição.

Em um estudo de caso sobre poluição sonora realizado nos bairros centrais da cidade de Curitiba Zorzal et al. (2003), verificaram que todos os bairros apontaram para níveis de ruídos além do tolerado pela saúde humana, ou seja, entre $61 \mathrm{~dB}(\mathrm{~A})$ e $86 \mathrm{~dB}(\mathrm{~A})$, o que fez os autores concluírem que há fortes indícios de aumento do estresse humano nessas localidades. Porém, os autores comentam que apesar dos níveis encontrados em Curitiba serem elevados, outras capitais brasileiras apresentam cerca de $10 \mathrm{~dB}(\mathrm{~A})$ a mais de nível de ruído do que os valores encontrados na capital paranaense, o que aponta uma necessidade de verificação e cumprimento das leis (municipais e nacionais) que regem ou abranjam a poluição sonora, principalmente onde o processo de urbanização se mostra elevado e/ou crescente. 
Santos (2001) comenta que a poluição sonora faz parte integrante das leis de poluição por suas conseqüências, e deve ser combatida, tanto pelo poder público quanto pela sociedade, individualmente ou coletivamente, colocando ainda que existem leis (Constituição Federal, art. 225) que diz ser direito dos cidadãos o meio ambiente equilibrado, "(...) o que não se pode considerar como tal em havendo poluição sonora, quer doméstica, urbana, industrial ou no trabalho".

Com base no estudo do uso do solo e com o devido suporte bibliográfico é possível identificar, delimitar e espacializar as fontes geradoras de poluição sonora e suas respectivas áreas de influência. Assim, essas áreas podem ser consideradas com menor qualidade ambiental (NUCCl, 1996, 1998, 2001 e 2008).

\subsection{INUNDAÇÕES FREQUENTES}

Outro problema decorrente do uso inadequado do solo em áreas urbanas são as inundações frequentes.

Segundo Nucci (2008), as inundações "estão relacionadas com a impermeabilização, que causa uma diminuição da infiltração no solo e um aumento do escoamento superficial (runoff)". A impermeabilização das superfícies associada à canalização dos córregos favorece o aumento no volume de vazão da água pelos canais de escoamento, que não suportando esse aumento de vazão, permite o transbordamento da água.

Ainda quanto às causas das inundações, Jedicke (1995) afirma que as chuvas torrenciais são fatores secundários das enchentes, "mais importante são as intervenções humanas nas várzeas que são as condições prévias para que os níveis de inundação tornem-se tão agudos". O autor ainda enfatiza que "uma política de aceleração do escoamento das águas nos últimos decênios favoreceu a não atuação do solo como armazenador e tampão para água" .

O que acontece normalmente nas cidades é a utilização de sistemas de drenagem para escoar as águas de chuva para rios e lagos, porém, "sistemas de drenagem transportam a água de um ponto para outro; eles não reduzem nem eliminam água, apenas mudam sua localização" (SPIRN, 1995). Ainda segundo a autora, com esses sistemas de drenagem, ruas, subterrâneos e estacionamentos 
próximos a esses sistemas estão protegidos contra as enchentes, enquanto localidades mais abaixo sofrem um dano maior com as inundações.

Entre as causas que podem acarretar estes eventos nas cidades está o fenômeno da Ilha de Calor que, segundo Lombardo (1985), “associada à concentração de elementos poluentes, favorece a formação de condensação, fato que condiciona freqüentes episódios de enchentes no centro da cidade", acrescentando ainda que "essas enchentes são intensificadas principalmente devido ao aumento das áreas impermeabilizadas pela pavimentação das ruas e avenidas e pela concentração de construções".

Lombardo (1985) aponta que no verão, devido a ilha de calor há uma "distorção no campo de precipitação da cidade", apontando que "os maiores problemas de enchente ocorrem justamente nas áreas com alto grau de impermeabilidade do terreno. O que coincide com os maiores picos da ilha de calor e de intensidade de chuvas". Segundo a autora isso se dá, provavelmente, pela influência da Metrópole (no caso de seu estudo a Metrópole Paulistana), associada à ilha de calor e à "situação sinótica favorável", possibilitando e ocasionando o "desenvolvimento e intensificação de convecção na região".

Outro problema relacionado às inundações é a quantidade e variedade de impurezas contidas nessas águas, acarretando diversos males, pois, "este líquido, atingindo coleções superficiais ou infiltrando-se no terreno até alcançar a água subterrânea, pode resultar em: efeitos negativos sobre a saúde humana; diminuição do oxigênio da água, excessiva turbidez, etc." (MOTA, 1999). O autor ainda salienta que a concentração de impurezas, depende, dentre vários fatores, principalmente do uso do solo (residencial, comercial, industrial ou outros); das atividades desenvolvidas na área (como construções, tráfego de veículos, etc.); de fatores relacionados com a duração, quantidade e freqüência da precipitação pluvial; e, das características do ambiente local (área pavimentada, tipo de pavimentação, estrutura e composição do solo, etc.).

Nas áreas onde a densidade populacional é alta e o solo se encontra impermeabilizado, Mota (1999) explica que "a presença de resíduos sólidos, de detritos de animais e de outras impurezas é comum na superfície dessas áreas, contribuindo para uma péssima qualidade das águas do escoamento". O autor 
ressalta que os momentos iniciais da precipitação são os de maior preocupação quanto a essas impurezas.

Segundo Brandão et al. (2001), uma questão a ser levada em conta é a idéia de que alguns dos mais importantes aspectos ligados ao crescimento urbano, incluindo a ausência de normas rígidas para a regulação do crescimento horizontal e vertical, certamente têm contribuído para o aumento da freqüência dos temporais, e que isso não deve ser tratado como anomalia climática, "mas sim como desvios produtores de acidentes de grande repercussão socioeconômica, que são sensivelmente agravados pela ação antrópica". Jedicke (1995) coloca que "a enchente catastrófica do presente deve ser o motivo suficiente, do ponto de vista técnico e político, para provocar uma discussão e em seguida levar a ações práticas", acrescentando que, "interessante seria comparar os danos econômicos da enchente com os custos de um tratamento abrangente de suas causas". A autora coloca essa visão e propõe a discussão mostrando sobre os danos econômicos que normalmente recaem sobre a classe baixa e os custos de tratamento que recairiam sobre a classe média.

Nesse contexto, as áreas com riscos de alagamento também podem ser mapeadas e inseridas como situação que diminui a qualidade ambiental (NUCCI, 1996, 1998, 2001 e 2008).

\subsection{VERTICALIDADE E DENSIDADE DEMOGRÁFICA}

Nucci et al. (2005) consideram que as edificações acima de 4 pavimentos promovem a intensificação do uso e ocupação do solo com impactos negativos na água, no solo e no ar. Para evitar o uso de elevadores e, consequentemente, economizar a energia, 6 pavimentos é o limite máximo para a cidade de Dongtan, na China (PLANETA SUSTENTÁVEL, 2008).

Lötsch (1984) coloca como conseqüências negativas da verticalização prédios com mais de quatro pavimentos, pois, as crianças podem se tornar dependentes do elevador, porém, não lhes é permitido andar sozinhas no elevador, e, também não podem brincar nos corredores, então, ao invés de brincarem ao ar livre, com jogos e esportes, ficam em seus apartamentos, assistindo televisão. 
Nucci (2008) comenta que "os médicos dizem que crianças que vivem em grandes edifícios têm desenvolvimento muscular inferior ao desejável, palidez e agressividade".

Com o crescimento das cidades os novos e altos edifícios passaram a ocupar todo o espaço possível no lote, substituindo a paisagem horizontal das grandes casas com jardins. Macedo (1987) afirma que a partir do crescimento da verticalização nos centros urbanos, as atividades antes realizadas ao ar livre e junto as habitações, em jardins e quintais, agora devem ser feitas em espaço público (ruas, calçadas, praças, etc.) ou simplesmente serem suprimidas.

A ocupação dos espaços livres de edificação pelos altos edifícios também pode ser considerada como um fator causador da diminuição da qualidade do meio ambiente. Oke (1981 apud LOMBARDO, 1985) coloca que "a verticalização cria problemas tais como: sobrecarga da rede viária, de esgoto, de água, e uma maior concentração populacional residente ou não". O autor ainda salienta as variações causadas no meio físico, sendo uma das mais consideráveis a climática, onde "os corredores de edifícios formam um verdadeiro "canyon urbano".

Danni-Oliveira et al. (2000) apontam que "ao estudarem a influência da verticalização nas temperaturas do ar, observaram que os valores mais acentuados coincidiram na maioria dos casos com as áreas de maior verticalidade (transecto das Ruas Pe. Anchieta e Bruno Filgueira)", no município de Curitiba/PR.

Quanto ao acúmulo de calor, Lombardo (1985) afirma que em núcleos de grandes edificações há a produção de stress térmico, ou ilha de calor, e em localidades de clima tropical isso pode causar desconforto térmico, ultrapassando os limites de tolerância dos habitantes.

Myrup (1969 apud LOMBARDO, 1985) aponta entre os determinantes da ilha de calor nas cidades, "o aumento da rugosidade (pela presença de edifícios), agravando a turbulência que age para transferir calor para cima, ao mesmo tempo que diminui o escoamento zonal". As propriedades térmicas dos edifícios e dos materiais de pavimentação absorvem energia durante o dia, e a noite emitem radiação de onda longa, o que ocasiona excesso de temperatura durante a noite, maior que durante o dia.

Xavier e Xavier (1997 apud MOTA 1999), verificando as alterações climáticas na Região Metropolitana de Fortaleza, "constataram um decréscimo na velocidade 
média do vento, da ordem de 50\%, entre 1974 e 1995", concluindo que o principal fator para essa redução reside, provavelmente, "no uso indiscriminado do solo urbano, em termos de uma crescente verticalização, forçada pela especulação imobiliária (...), cuja massa de construções verticalizadas funciona como um barramento artificial aos ventos". Porém, os autores ressaltam que estudos mais detalhados são necessários para a comprovação deste fenômeno.

A verticalização pode ainda trazer problemas em relação à saúde dos cidadãos que moram em apartamentos ou casas que sejam encobertos pelo sombreamento de prédios mais altos.

A figura 1 aponta as conseqüências negativas para a qualidade ambiental do adensamento populacional, principalmente causado pela verticalização, nas áreas urbanas.

Dessa forma, as áreas com alta densidade demográfica e muito verticalizadas podem ser, também, consideradas como áreas com menor qualidade ambiental (NUCCI, 1996, 1998, 2001 e 2008). 
FIGURA 1 - FLUXOGRAMA DAS CONSEQÜÊNCIAS DA VERTICALIZAÇÃO E DO ADENSAMENTO POPULACIONAL URBANO

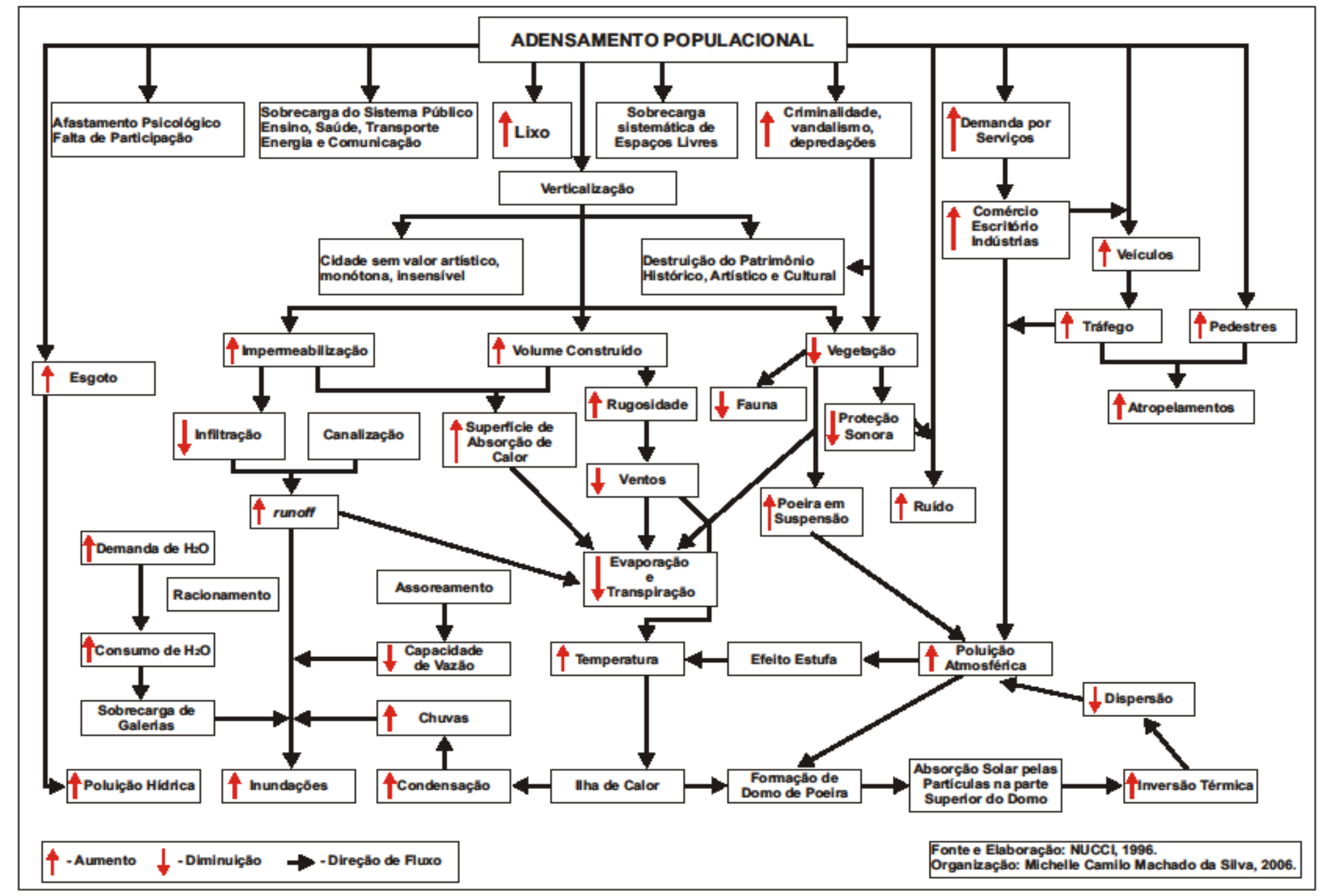

FONTE: NUCCI (1996 e 2001) 


\subsection{EXEMPLOS DA UTILIZAÇÃO DOS CRITÉRIOS DA QUALIDADE} AMBIENTAL URBANA

Apenas como exemplo, apresentam-se a seguir duas áreas do município de Curitiba que podem ser consideradas como de boa qualidade ambiental.

A figura 2 mostra uma área na qual se encontram conjuntos de edifícios de até quatro pavimentos, com uso exclusivamente residencial e com um espaço livre público, de fácil acesso, apresentando infra-estrutura de lazer (ativo e passivo) para diferentes faixas etárias, com vegetação (herbácea, arbustiva e arbórea) e sem contato com veículos automotivos. As calçadas são arborizadas (FIGURA 3) e conduzem aos serviços de primeira necessidade (padarias, um pequeno shopping center, farmácia, etc) e as ruas não apresentam tráfego intenso de veículos. Em uma das ruas há uma feira-livre semanal que abastece os residentes com diversos produtos. Em termos de uso e ocupação do solo, há apenas a linha ferroviária que tangencia ao leste a área e que colabora para a diminuição da qualidade ambiental.

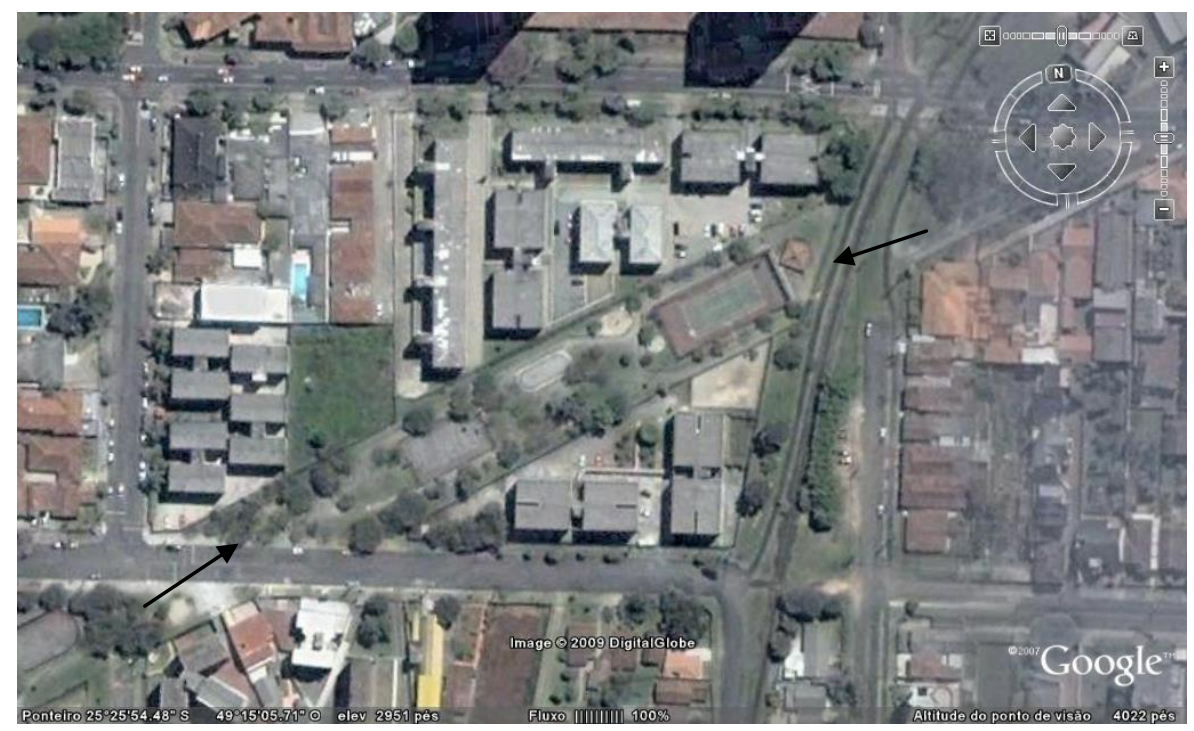

FIGURA 2 - VISTA AÉREA (IMAGEM DE SATÉLITE) DE UM TRECHO DA AVENIDA SETE DE SETEMBRO E ADJACÊNCIAS, ENTRE OS BAIRROS CRISTO REI E ALTO DA XV (CURITIBA/PR). O ESPAÇO DE USO PÚBLICO E LIVRE DE EDIFICAÇÃO, NO CENTRO DA FIGURA, É NOMEADO PELA PREFEITURA COMO JARDIM AMBIENTAL I.

FONTE: GOOGLE EARTH (2009) 


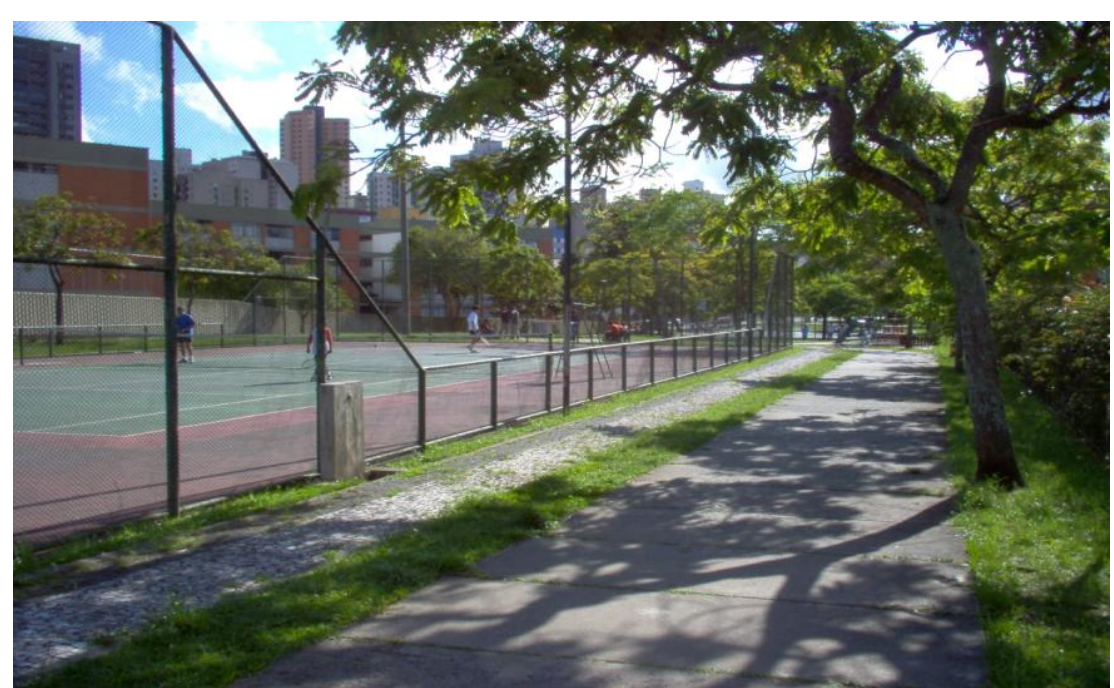

FIGURA 3 - DETALHE DA INFRA-ESTRUTURA DE LAZER DO JARDIM AMBIENTAL I.

FONTE: BUCCHERI-FILHO (2006)

As ruas sem saída e que terminam em um espaço livre também favorecem a qualidade ambiental. A figura 4 mostra uma área localizada no bairro Juvevê, em Curitiba, na qual 5 ruas sem saída terminam em um espaço de uso público e livre de edificação. As calçadas são bem arborizadas e as ruas são pouco movimentadas o que torna o caminhar seguro e agradável para todas as idades. O espaço livre é pequeno e com pouca infra-estrutura de lazer, sendo, portanto, mais propício para o uso de crianças menores e para o descanso de adultos nos bancos dispostos ao redor do espaço. Como pontos negativos que estão diminuindo a qualidade ambiental do bairro estão a invasão de outros usos diferentes do residencial, a construção de edifícios de mais do que 4 pavimentos e a abertura das ruas sem saída com a liberação e aumento do fluxo de veículos. 


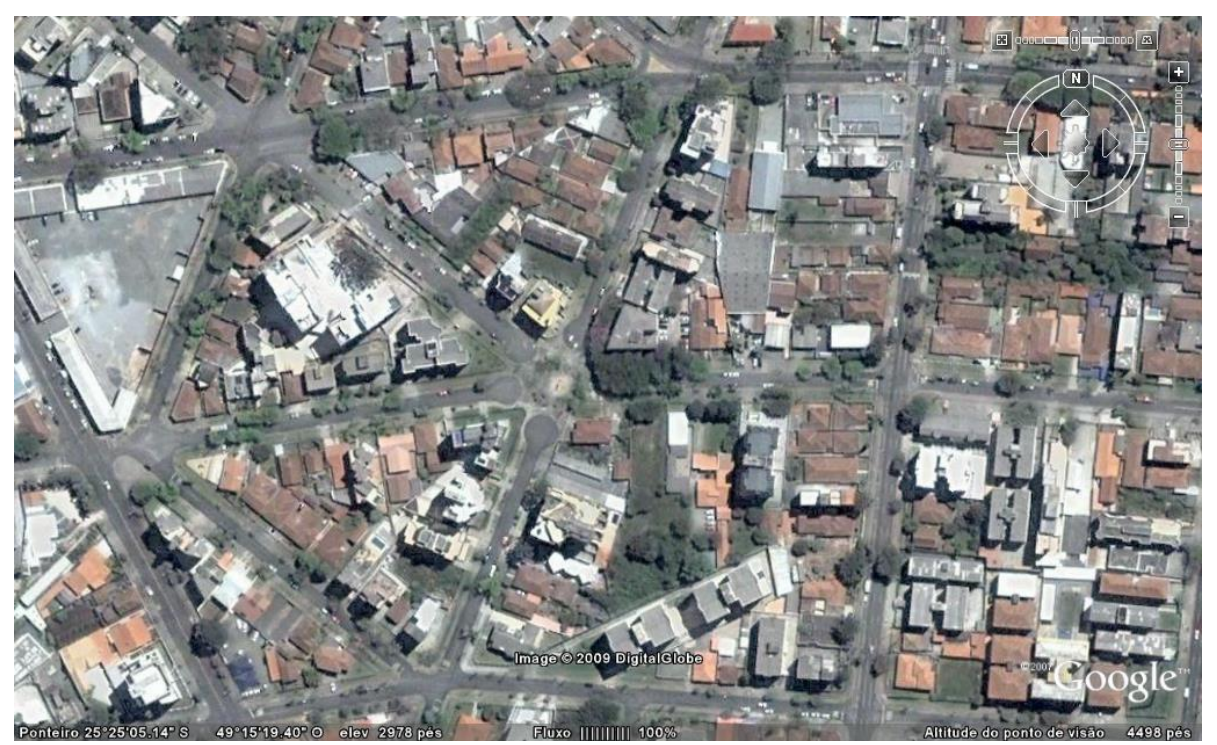

FIGURA 4 - TRECHO DA RUA PARAGUASSU, NO BAIRRO JUVEVÊ (CURITIBA/PR). NO CENTRO DA IMAGEM HÁ UM PEQUENO ESPAÇO DE USO PÚBLICO E LIVRE DE EDIFICAÇÃO COM VEGETAÇÃO E INFRAESTRUTURA PARA RECREAÇÃO DE CRIANÇAS PEQUENAS E CINCO RUAS “SEM-SAÍDA” DÃO ACESSO AO ESPAÇO.

FONTE: GOOGLE EARTH (2009)

\section{CONCLUSÃO}

Certamente que o processo de urbanização sempre provoca alterações nos processos naturais, porém, se o crescimento, tanto em área (horizontal) quanto em volume (vertical) for rápido demais e sem se considerar o planejamento da paisagem, as conseqüências negativas para a qualidade ambiental serão maiores.

Um ambiente com qualidade e o desenvolvimento sócio-econômico concorrem diretamente entre si e geralmente, as questões econômicas é que prevalecem. Os resultados deste domínio são a poluição, os congestionamentos, os ruídos, a falta de espaços livres públicos e de áreas verdes. Por isso a verificação da qualidade ambiental nas cidades é cada vez mais importante.

Considerando o ambiente urbano como o conjunto de fatores do meio físico urbano e o conceito de qualidade ambiental urbana como componente do conceito de qualidade de vida, a qualidade ambiental urbana pode ser definida 
como a amplitude de condições favoráveis do ambiente urbano, que suprem as necessidades fisiológicas e psicológicas do ser humano.

Pode-se avaliar a qualidade do ambiente urbano por meio das consequências, para o meio físico e para os seres humanos, inferidas com base no uso e na ocupação do solo. Podem, por exemplo, ser inferidas as consequências para o clima urbano por meio da espacialização e da quantificação dos pavimentos das edificações ou para a qualidade do ar, da água e do solo, com base na poluição que possivelmente os usos potencialmente poluidores, tais como postos de gasolina, serralherias, mecânicas, vias com tráfego intenso etc., estejam gerando. As áreas com riscos de alagamento também podem ser mapeadas e inseridas como situação que diminui a qualidade ambiental. Áreas sem vegetação, sem espaços livres públicos, com alta densidade demográfica e muito verticalizadas podem ser, também, consideradas como áreas com menor qualidade ambiental.

Os estudiosos da saúde estão convictos sobre a importância das atividades física regulares para as pessoas. Dessa forma o desenho dos bairros com base em uma distribuição dos serviços, dos espaços livres, dos caminhos abrigados ou não da insolação e dos ruídos e presença de transeuntes podem criar oportunidades e estimular caminhadas que estejam associadas às atividades diárias como ir às compras ou ao trabalho. Pesquisas demonstram que o uso misto dos bairros e ambientes que respeitam a escala humana colaboram para o aumento da frequência das caminhadas (JACKSON, 2003).

O baixo tráfego de veículos e a presença da vegetação podem criar um ambiente agradável, favorecendo as atividades físicas dos cidadãos, como um tipo de rua desenvolvida na Holanda, a woonerf (pátio residencial) que acentua o papel social e ambiental da rua. Nestas ruas os carros passam em baixa velocidade pela presença de obstáculos, canteiros e árvores. Algumas cidades alemãs e americanas implementaram esse conceito de rua e obtiveram benefícios marcantes da qualidade do ar local.

O ser humano, mesmo nas cidades, pode usufruir da natureza e manter um nível de relação equilibrado com o ambiente físico para que este continue a desempenhar parte de seus processos ecológicos que acabam oferecendo serviços benéficos para o meio urbano. 
Nos últimos tempos tem se desenvolvido um repensar sobre a forma de consumo dos recursos bem como sobre os impactos negativos para a qualidade ambiental e de vida nas cidades que precisam considerar os limites do crescimento e do desenvolvimento se almejam uma boa qualidade ambiental.

\section{REFERÊNCIAS}

AYOADE, J. Introdução à climatologia para os trópicos. São Paulo: DIFEL, 1983. 332p.

BELEM, A. L. G.; NUCCI, J. C.. Espaços urbanos no bairro de Santa Felicidade, Curitiba/PR: conceito, classificação, quantificação e distribuição. Geografia. Ensino \& Pesquisa, v. 12, p. 972-985, 2008.

BRANCO, S. M. Poluição do ar. São Paulo: Ed. Moderna, 1995. (Coleção Polêmica).

BRANDÃO, A. N. P. M.; SILVEIRA JUNIOR D. R.; TAVARES, J. C.; DANTAS, M. E. Mapa de isoietas totais anuais: bacias dos rios Paraíba do Sul, Itabapoana e Litorâneas do Estado do Rio de Janeiro, período 1968 - 1995. In: CPRM. Serviço Geológico do Brasil. Rio de Janeiro: geologia, geomorfologia, geoquímica, geofísica, recursos minerais, economia mineral, hidrogeologia, estudos de chuvas intensas, solos, aptidão agrícola, uso e cobertura do solo, inventário de escorregamentos, diagnóstico geoambiental. Rio de Janeiro: CPRM: Embrapa Solos; [Niterói]: DRM-RJ, 2001. 1 CDROM.

BRASIL. Lei Federal no 6.938, de 31 de agosto de 1981. Política Nacional do Meio Ambiente. Disponível em: http://www.planalto.gov.br/ccivil_03/Leis/L6938org.htm. Acesso em: 18/07/2006.

BRASIL. Constituição da República Federativa do Brasil. Distrito Federal, 1988. Disponível em: http://www.planalto.gov.br/ccivil 03/constituicao/constitui\%C3\%A7ao.htm Acesso em 15 julho 2009.

BRASIL. Lei Federal no 10.257, de 10 de julho de 2001. Estatuto da Cidade. Disponível em: WWW.planalto.gov.br/ccivil 03/Leis?LEIS 2001/L 10257.htm Acesso em: 20/07/2009.

BRASIL. Lei Federal no 12.305, de 02 de agosto de 2010. Política Nacional de Resíduos Sólidos. Disponível em: WWW.planalto.gov.br/ccivil 03/Leis?LEIS 2001/L 12.305.htm Acesso em: 16/11/2010. 
BUCCHERI-FILHO, A. T. Qualidade ambiental no Bairro Alto da XV, Curitiba/PR. Dissertação (Mestrado) - Setor de Ciências da Terra, Universidade Federal do Paraná, Curitiba. $2006.28 \mathrm{p}$. www.geografia.ufpr.br/laboratorios/labs/?pg=publicacoes-php Acesso em 15 dezembro 2008.

BUCCHERI FILHO, A. T. O planejamento dos espaços de uso público, livres de edificação e com vegetação (EUPLEVs) no município de Curitiba, PR: planejamento sistemático ou planejamento baseado em um modelo oportunista? 226p. Tese (Doutorado) - Setor de Ciências da Terra, Universidade Federal do Paraná, Curitiba. 2010. Disponível em http://dspace.c3sl.ufpr.br/dspace/bitstream/1884/24093/1/TESE\%20Alexandre \%20Theobaldo\%20Buccheri\%20Filho.pdf . Acesso em 20 outubro 2010.

CALIXTO, A. O Ruído gerado pelo tráfego de veículo em "Rodovias Grandes Avenidas" Situadas dentro do Perímetro Urbano de Curitiba, Analisado sob Parâmetros Acústicos Objetivos e seu Impacto Ambiental. Dissertação (Mestrado de Engenharia Mecânica) - Universidade Federal do Paraná. Curitiba, 2002. 125p.

CAVALHEIRO, F.; NUCCI, J.C; GUZZO, P.; ROCHA, Y.T. Proposição de terminologia para o verde urbano. Boletim Informativo da SBAU (Sociedade Brasileira de Arborização Urbana), ano VII, n. 3 - Jul/ago/set de 1999, Rio de Janeiro, p. 7.

CURITIBA. Prefeitura Municipal. Diagnóstico Ambiental do Município de Curitiba. em: http://www.curitiba.pr.gov.br/publico/secretaria. $\cdot$ sppx?idf=211\&servico=26. Acesso em: Abril/2006.

DANNI-OLIVEIRA, I. M. A cidade de Curitiba e a poluição do ar. In: Carlos Augusto F. Monteiro; Francisco Mendonça. (Orgs.). Clima Urbano. Ed. São Paulo: Contexto, 2003, v. 1, p. 155-174.

DANNI-OLIVEIRA, I.M.; BAKOPNYIL,S.M.C.; BRITTO,D.M.; DANI, I.; IURK, J.N.; LOPES, E.A .; MARQUES, A .C. PINHEIRO,C.F.;SANTIS,D.G.D.; TELES, M.A.A .; VESTENA,L.R.;WATANABE,B. Implicações da verticalização no perfil térmico urbano: exemplo de Curitiba-PR. In: IV SBCG, Anais... Rio de Janeiro, 2000:10p.

DINIZ, F. B. Impacto ambiental das emissões sonoras de subestações de energia elétrica na cidade de Curitiba. Dissertação - Faculdade de Engenharia Mecânica, Universidade Federal do Paraná. Curitiba, 2003.121p.

DREW, D. Processos interativos homem-ambiente. $2^{a}$ Edição - Rio de Janeiro, Ed. Bertrand Brasil S.A., 1989.

FREIRIA, N.T. Qualidade ambiental urbana. Engenharia e Construção, Curitiba v. n.58, p. 24-32, jul. 2001. 
GARCIA, F. E. S. Cidade espetáculo: política, planejamento e city marketing. Curitiba: Palavra, 1997.

HOUGH, M. Naturaleza y ciudad. Planificacion urbana y processos ecologicos. Barceloma: G. Gilli, 1998. 315p.

HOWARD, E. Cidades - Jardins de amanhã. São Paulo: Ed. Hucitec, 1996.

JACKSON, L.E. The relationship of urban design to human health and condition. Landscape and Urban Planning 64 (2003) 191-200.

JEDICKE, E. Enchente: tempo para pensar nas conseqüências. Boletim Informativo da SBAU, ano II, №1, março de 1995, Botucatu/SP (Trad. P.C.D. Del Picchia).

JIM, C.Y. Tree-canopy characteristics and urban development in Hong Kong. The Geographic Review, v.79, n.2. Lawrence: American Geographical Society, p. 210-255, 1989.

KAMP, I. van; LEIDELMEIJER, G. M.; HOLLANDER, A. Urban environmental quality and human well-being: towards a conceptual framework and demarcation of concepts; a literature study. Landescape and Urban Planning, 65,2003 , p. $5-18$.

LLARDENT, L. R. A. Zonas verdes y espacios livres en la ciudad. Madri: Inst. De Estudios de Administración Local, 1982.

LOMBARDO, M.A. Ilha de calor nas metrópoles. O exemplo de São Paulo. São Paulo, Hucitec, 1985.

LÖTSCH, B. In search of human scale. Garten und Landschaft n.6, 1984, ed. DGGL, Zeitschrift der Deutschen Gessellschaft für Garten kunst und Landschaftspflege p.19-26.

LUCHIARI, A. Identificação da cobertura vegetal em áreas urbanas por meio de produtos de Sensoriamento Remoto e de um Sistema de Informação Geográfica. Revista do Departamento de Geografia, São Paulo, n.14, p.4758, 2001.

MACEDO, S.S. Higienópolis e arredores. Processo de mutação de paisagem urbana. Edusp/PINI, 1987, 352p.

MARGULIS, S. Meio ambiente: aspectos técnicos e econômicos. 2aㅡ Ed. Brasília, IPEA, 1996.

MASCARÓ, L. Ambiência urbana. Porto Alegre, Ed. Sagra, DC Luzzatto, 1996.

MONTEIRO, C. A. F. Teoria e clima urbano. São Paulo: IGEOG/USP, 1976. 
MOTA, S. Urbanização e mio ambiente. Rio de Janeiro, ABES, 1999, 352p.

MOURA, A. R. Qualidade ambiental urbana no bairro de Santa Cecília (centro de São Paulo/SP): estudo comparativo e de monitoramento dos anos de 1992 e 2008. 213f. Dissertação (Mestrado) - Setor de Ciências da Terra, Universidade Federal do Paraná, Curitiba. 2010.

MOURA, A.R.; NUCCI, J.C. Análise da cobertura vegetal de Santa Felicidade, Curitiba/PR. XI Simpósio Brasileiro de Geografia Física Aplicada. Anais ... USP, São Paulo, 2005

MURGEL, E. Barreiras acústicas rodoviárias. Engenharia, São Paulo, v.,n.532, p.60-65, 1999.

$\mathrm{NUCCl}$, J. C. Qualidade ambiental e adensamento: um estudo de Planejamento da Paisagem do distrito de Santa Cecília (MSP). Tese de doutorado. Universidade de São Paulo. Programa de Pós-Graduação em Geografia Física. 1996.

$\mathrm{NUCCl}$, J. C. . Metodologia para determinação da qualidade ambiental urbana. Revista do Departamento de Geografia (USP), São Paulo, v. 10, n. 12, p. 209-224, 1998.

$\mathrm{NUCCl}$, J. C. Qualidade Ambiental e Adensamento Urbano: um estudo de ecologia e planejamento da paisagem aplicado ao distrito de Santa Cecília

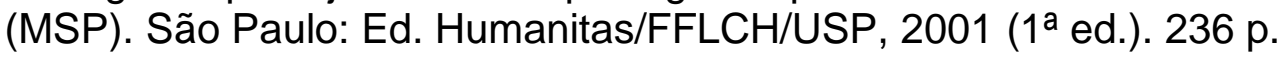

NUCCl, J. C. Qualidade Ambiental e Adensamento Urbano: um estudo de ecologia e planejamento da paisagem aplicado ao distrito de Santa Cecília (MSP). Curitiba: Edição do autor (e-book), 2008. 142p. Disponível: www.geografia.ufpr.br/laboratorios/labs/?pg=publicacoes-php. Acesso em 15 dezembro 2008.

NUCCl, J. C. Ecologia e Planejamento da Paisagem. In: Douglas Gomes dos Santos; João Carlos Nucci. (Org.). Paisagens Geográficas. Um tributo a Felisberto Cavalheiro. Campo Mourão: Editora da FECILCAM, 2009, p. 50-64. Disponível em http://www.fecilcam.br/editora/index.php?option=com content\&task=blogcatego ry\&id=6\&ltemid=12 Acesso em 28 abril 2010.

NUCCl, J. C. Aspectos teóricos do Planejamento da Paisagem. In: Planejamento da Paisagem como subsídio para a participação popular no desenvolvimento urbano. Estudo aplicado ao bairro de Santa Felicidade Curitiba/PR. / Organização de João Carlos Nucci. Curitiba: LABS/DGEOG/UFPR, 2010, p. 14-25. Disponível em www.geografia.ufpr.br/laboratorios/labs/?pg=publicacoes-php Acesso em 20 agosto 2008.

NUCCI, J.C.; CAVALHEIRO, F. Cobertura vegetal em áreas urbanas - conceito e método. GEOUSP n.6, 1999, p.29-36. 
NUCCI, J. C.; KRÖKER, R.; SCHMIDT, E.; BUCCHERI-FILHO, A. T. Mapeamento da qualidade ambiental no bairro Hauer, Curitiba/Paraná. In: International Congress on Environmental Planning and Urbanization. Anais... Brasília, 2005.

PAZ, E. C. Estudo de um modelo de avaliação e predição acústica para ruído de tráfego rodoviário. Curitiba, 2004. xxxviii, 417 f.: il. Dissertação (mestrado), setor de tecnologia, Universidade Federal do Paraná.

PLANETA SUSTENTÁVEL. Cidade dos sonhos. Disponível em $<$ planetasustentavel.abril.com.br> Consultado em 06 maio 2008.

PUPPI, I. C. Estruturação sanitárias das cidades. CETESB, São Paulo. Ed. UFPR, sem data.

REGAZZI, R.D.; ARAÚJO G.M. Perícia e avaliação de ruído e calor passo a passo. Teoria e Prática. Rio de Janeiro: (s.n.), 2002.

SANTOS, A.S.R. Poluição sonora e sossego público. Revista Meio Ambiente Industrial, São Paulo, n.30, p.54-55, jun. 2001.

SCHMIDT, E. Avaliação da qualidade ambiental urbana do bairro Santa Felicidade, Curitiba/PR. 115 f. Dissertação (Mestrado) - Setor de Ciências da Terra, Universidade Federal do Paraná, Curitiba. 2009. Disponível em http://dspace.c3sl.ufpr.br:8080/dspace/handle/1884/18536 . Acesso em 23 novembro 2009.

SITTE, C. A construção das cidades segundo seus princípios artísticos. São Paulo, Ed. Ática, 1992 (1º ed. De 1889), 239p.

SPIRN, A.W. O Jardim de Granito: A Natureza no Desenho da Cidade. São Paulo, Editora da Universidade de São Paulo, 1995.

SUKOPP, H.; WERNER, P. Naturaleza em las ciudads. Madri, 1991.

TONETTI, E.L. POTENCIALIDADES DE ADENSAMENTO POPULACIONAL POR VERTICALIZAÇÃO DAS EDIFICAÇÕES E QUALIDADE AMBIENTAL URBANA NO MUNICÍPIO DE PARANAGUÁ, PARANÁ, BRASIL. Projeto de Tese (Doutorado) - Setor de Ciências da Terra, Universidade Federal do Paraná, Curitiba. 2010. Projeto em andamento.

TRICART, J. Ecodinâmica. Fundação Instituto Brasileiro de Geografia e Estatística. Superintendência de Recursos Naturais e Meio Ambiente. Diretoria Técnica. Rio de janeiro, 1977. 97p. il.

WORLD HEALTH ORGANIZATION - WHO (UK). Résume d'Orientation des Directives de IÓMS elatives au Bruit dans Enviromental. Disponível em: <http://www.who.int/docstore/peh/noise/bruit.htm> . Acesso em: 08 abr 2005. 
ZORZAL, F.M.B.; BRUNS, R. de; TONIN, A.K.; COSTA, C.; DIESEL, A.;BORTOLI, P.S. de. - Estudo do ruído frente à legislação. Engenharia e Construção, São Paulo, V.07, n.95, p.32-38, ago.2004.

ZORZAL, F.M.B.; DIESEL, A.; BORTOLI, P.S. de.; PEREIRA, L.C. - Carta de Ruído da Cidade de Curitiba enquanto poluição sonora difusa. Engenharia e Construção, Curitiba, v., n.81, p.58-63, jun. 2003.

(Recebido em 02.07.2010. Aceito em 20.02.2011) 